\title{
ARTICLE
}

\section{Low-Activation Multilayer Shielding Structure of Light Water Reactor Using Various Types of Low-Activation Concrete}

\author{
Masaharu KINNO $^{1 *}$, Ken-ichi KIMURA ${ }^{1}$, Yusuke FUJIKURA ${ }^{1}$, Hirokazu NISHIDA ${ }^{1}$, \\ Norichika KATAYOSE $^{1}$, Taiichiro MORI ${ }^{2}$, Ryoetsu YOSHINO ${ }^{2}$, Takao TANOSAKI ${ }^{3}$, \\ Koki ICHITSUBO ${ }^{3}$, Mikihiro NAKATA ${ }^{4}$, Tomohiro OGATA ${ }^{4}$, Mikio UEMATSU ${ }^{5}$, \\ Katsumi HAYASHI ${ }^{6}$, Mitsuru SATO $^{7}$, Mizuo SAKAKIBARA ${ }^{7}$, Shigeru ITO ${ }^{8}$, \\ Katsuyoshi YAMAGUCHI ${ }^{9}$, Manabu SATOU ${ }^{10}$ and Akira HASEGAWA ${ }^{10}$ \\ ${ }^{1}$ Fujita Corporation,Ono 2025-1,Atsugi, Kanagawa,243-0125,Japan \\ ${ }^{2}$ Denki Kagaku Kogyo Kabushiki Kaisha,Omi 2209,Itoigawa,Niigata,949-0393,Japan \\ ${ }^{3}$ Taiheiyo Cement Corporation,Taisaku 2-4-2,Sakura,Chiba,285-8655,Japan \\ ${ }^{4}$ Mitsubishi Heavy Industries, Ltd., Wadasaki 1-1-1,Hyogo, Kobe, 652-8585,Japan \\ ${ }^{5}$ Toshiba Corporation, Shinsugita 8, Isogo, Yokohama, 235-8523,Japan \\ ${ }^{6}$ Hitachi-GE Nuclear Energy, Ltd., Saiwai 3-1-1, Hitachi, 317-0073,Japan \\ ${ }^{7}$ Nippon Steel Techno Research Corporation, Sakato 3-2-1, Takatsu, Kawasaki, 213-0012,Japan \\ ${ }^{8}$ Tohoku Electric Corporation, Inc., Honcho 1-7-1, Aoba, Sendai,980-8550,Japan \\ ${ }^{9}$ Itochu Techno-Solutions Corp., Kasumigaseki 3-2-5, Chiyoda-Ku, Tokyo, 100-6080, Japan \\ ${ }^{10}$ Tohoku University, Aramaki, Aoba, Sendai,980-8579,Japan
}

\begin{abstract}
Low-activation multilayer shielding structure of light water reactor has been designed using various types $(1 / 10$, $1 / 100,1 / 1,000$ and 1/10,000) of low-activation concrete composed of low-activation raw materials. The term " $1 / 10$ of low-activation concrete" denotes that the activity reduction rate to ordinary concrete is designed to be $1 / 10$. As an example, iterative calculations of induced activities and $\sum \mathrm{Di} / \mathrm{Ci}$ (Di: concentration of radionuclide i, Ci: clearance level of radionuclide i) values of multilayer model for the Japan Power Demonstration Reactor (JPDR) have been performed by using a discrete ordinate code. It is concluded that most of the shielding concrete of JPDR would be classified below clearance level on decommissioning by adopting such low-activation multilayer shielding structures.

KEYWORDS: low-activation, concrete, neutron irradiation, induced activity, clearance level
\end{abstract}

\section{Introduction}

Inner part of biological shielding concrete wall around a reactor is classified as radioactive waste in terms of its clearance level recommended by the International Atomic Energy Agency (IAEA-RS-G-1.7 ${ }^{1)}$ ). Here, "clearance" denotes the radioactive classification permissible for disposing of material as non-radioactive waste. Reutilization of this concrete after decommissioning will be indispensable in the management of radioactive waste disposal operations. For that reason, various types $(1 / 10,1 / 20,1 / 30,1 / 50,1 / 100$, $1 / 300,1 / 1,000,1 / 3,000$ and $1 / 10,000)$ of low-activation concrete (LAC) composed of low-activation raw materials have been developed. ${ }^{2), 3), 4)}$ These types of low-activation concrete have been developed to reduce generation of residual radioactivities in "onion" type of steel plate concrete structure. The aim of this study is to estimate the ability of low-activation for such multilayer shielding structures.

\section{Low-activation concrete for multilayer shielding structure}

Table 1 shows low-activation raw materials and reference low-activation concrete. The term "1/10" type of

*Corresponding author, E-mail: kinno@fujita.co.jp

(C) Fujita corporation

(C) Atomic Energy Society of Japan low-activation concrete denotes that the activity reduction rate to ordinary concrete is designed to be $1 / 10$. This reduction ratio of $\Sigma \mathrm{Di} / \mathrm{Ci}$ (Di: concentration of radionuclide $\mathrm{i}$, $\mathrm{Ci}$ : clearance level of radionuclide i, cited from IAEA-RS-G-1.7, assuming the neutron flux of an inner part of the BWR biological shield, $40 \mathrm{yr}$ of operation, and $6 \mathrm{yr}$ of cooling) is normalized to the andesite concrete, which is considered to be an "average concrete".

Mixing works of various types $(1 / 10,1 / 20,1 / 30,1 / 50$, $1 / 100,1 / 300,1 / 1,000,1 / 3,000$ and 1/10,000) of low-activation concrete have been performed based on the data obtained in the screening tests of raw materials. In this project, a new type of low-activation cement, that is, "low-activation low-heat Portland cement",5) and also a new type of low-activation additive, that is, "low-activation calcium-aluminates-silicate (CAS) additive, ${ }^{6}$ have been developed. The ingredients of major and minor elements for $1 / 10,1 / 100,1 / 1,000$ and $1 / 10,000$ types of low-activation concrete and for the Japan Power Demonstration Reactor (JPDR) concrete are listed in Table 2. For almost types of specimens, chemical analyses were adopted for determining the concentrations of major and minor elements. The water content of JPDR concrete was adjusted to $9.0 \mathrm{w} \%$ according to previous study. ${ }^{7)}$

\section{Activation analyses of multilayer low- activation concrete using JPDR experiment}


Table 1 Low-activation raw material and reference low-activation concrete

\begin{tabular}{|c|c|c|c|}
\hline \multicolumn{2}{|r|}{ Item } & \multicolumn{2}{|l|}{ Name of material } \\
\hline \multirow{3}{*}{$\begin{array}{l}\text { Low- } \\
\text { activation } \\
\text { raw } \\
\text { material }\end{array}$} & $\begin{array}{c}\text { Aggregate } \\
\text { (Coarse, Fine) }\end{array}$ & \multicolumn{2}{|c|}{$\begin{array}{l}\text { Ordinary, Dunite, Serpentite, Limestone, Colemanite, Baryte, High purity } \\
\text { limestone, Quartzite, silica sand, Fused alumina, } \mathrm{B}_{4} \mathrm{C} \text { sand } \mathrm{d}^{\mathrm{a})} \text {, etc. }\end{array}$} \\
\hline & Cement & \multicolumn{2}{|c|}{$\begin{array}{l}\text { Ordinary Portland, Moderate-heat Portland, Low-heat Portland, White cement, } \\
\text { Low-activation low-heat cement }{ }^{\text {b) }} \text {, High alumina cement, etc. }\end{array}$} \\
\hline & Additive & \multicolumn{2}{|c|}{$\begin{array}{l}\text { Fly ash, Blast furnace slag, Low-activation limestone powder, Low-activation } \\
\text { silica fume, Low-activation CAS additive }{ }^{\text {c }}, \mathrm{B}_{4} \mathrm{C}_{\text {powder }}{ }^{2} \text {, etc. }\end{array}$} \\
\hline \multirow{13}{*}{$\begin{array}{c}\text { Reference } \\
\text { low- } \\
\text { activation } \\
\text { concrete }\end{array}$} & Name of concrete & Reference compositions & $\sum \mathrm{D} / \mathrm{C}^{\mathrm{d})}$ \\
\hline & (Andesite concrete) & (Andesite aggregate + ordinary Portland cement) & 1 \\
\hline & $1 / 10$ low-activation concrete & $\begin{array}{l}\text { Limestone aggregate }+ \text { low-heat or moderate-heat or ordinary } \\
\text { Portland cement, etc }\end{array}$ & $1 / 10$ \\
\hline & $1 / 20$ low-activation concrete & $\begin{array}{l}\text { Limestone aggregate }+ \text { low-heat or moderate-heat or ordinary } \\
\text { Portland cement }+ \text { silica fume and/or limestone powder, etc }\end{array}$ & $1 / 20$ \\
\hline & $1 / 30$ low-activation concrete & $\begin{array}{l}\text { Limestone aggregate }+ \text { low-activation low-heat }{ }^{b)} \text { or white } \\
\text { Portland cement, etc }\end{array}$ & $1 / 30$ \\
\hline & $1 / 50$ low-activation concrete & $\begin{array}{l}\text { Limestone aggregate }+ \text { low-activation low-heat }{ }^{\text {b) }} \text { or white } \\
\text { Portland cement }+ \text { silica fume and/or limestone powder, etc }\end{array}$ & $1 / 50$ \\
\hline & $1 / 100$ low-activation concrete & $\begin{array}{l}\text { Limestone aggregate }+ \text { low-heat or moderate-heat or ordinary } \\
\text { Portland cement }+\mathrm{B}_{4} \mathrm{C} \text { powder, etc }\end{array}$ & $1 / 100$ \\
\hline & $1 / 300$ low-activation concrete & $\begin{array}{l}\text { Fused alumina aggregate }+ \text { high alumina cement }+ \text { low- } \\
\text { activation CAS additive, etc }\end{array}$ & $1 / 300$ \\
\hline & $1 / 1,000$ low-activation concrete & $\begin{array}{l}\text { Limestone aggregate }+ \text { low-activation low-heat }{ }^{\text {b) }} \text { or white } \\
\text { Portland cement }+\mathrm{B}_{4} \mathrm{C} \text { sand and/or powder, etc }\end{array}$ & $1 / 1,000$ \\
\hline & $1 / 3,000$ low-activation concrete & $\begin{array}{l}\text { Limestone or quartzite aggregate }+ \text { high alumina cement }+ \text { low- } \\
\text { activation CAS additive }+\mathrm{B}_{4} \mathrm{C} \text { powder, etc }\end{array}$ & $1 / 3,000$ \\
\hline & $1 / 10,000$ low-activation concrete & $\begin{array}{l}\text { Fused alumina aggregate }+ \text { high alumina cement }+ \text { low- } \\
\text { activation } \mathrm{CAS} \text { additive }+\mathrm{B}_{4} \mathrm{C} \text { sand and/or powder, etc }\end{array}$ & $1 / 10,000$ \\
\hline & $\mathrm{L} 2 \rightarrow \mathrm{L} 3$ low-activation concrete & $\begin{array}{l}\text { Dunite or Fused alumina aggregate + low-activation low-heat }{ }^{\mathrm{b})} \\
\text { or white Portland cement, etc }\end{array}$ & - \\
\hline & $\mathrm{L} 2 \rightarrow \mathrm{L} 3$ low-activation heavy mortar & $\begin{array}{l}\text { Dunite or Fused alumina aggregate }+ \text { high alumina cement }+ \\
\text { low- activation CAS additive, etc }\end{array}$ & - \\
\hline
\end{tabular}
a) (0.03-3) $\times 10^{21} / \mathrm{cm}^{3}$ of natural boron. b) Low-activation low-heat Portland cement developed in this project (2007) (Ref. 5). c) Calciumaluminates-silicate additives developed in this project (2007) (Ref.6). d) Calculated assuming the neutron flux of an inner part of the BWR biological shield, 40 yr of operation and 6 yr of cooling. The radionuclides of ${ }^{3} \mathrm{H},{ }^{14} \mathrm{C},{ }^{36} \mathrm{Cl},{ }^{41} \mathrm{Ca},{ }^{54} \mathrm{Mn},{ }^{55} \mathrm{Fe},{ }^{60} \mathrm{Co},{ }^{59} \mathrm{Ni},{ }^{63} \mathrm{Ni},{ }^{65} \mathrm{Zn},{ }^{94} \mathrm{Nb},{ }^{125} \mathrm{Sb}$, ${ }^{133} \mathrm{Ba},{ }^{134} \mathrm{Cs},{ }^{137} \mathrm{Cs},{ }^{151} \mathrm{Sm},{ }^{152} \mathrm{Eu},{ }^{154} \mathrm{Eu}$ and ${ }^{155} \mathrm{Eu}$ are used in this calculation.

Table 2 Ingredients of major and minor elements for reference low-activation concrete and JPDR concrete

\begin{tabular}{|c|c|c|c|c|c|}
\hline \multirow[t]{2}{*}{ Element } & $\begin{array}{c}1 / 10,000 \\
\text { low-activation } \\
\text { concrete }\end{array}$ & $\begin{array}{c}1 / 1,000 \\
\text { low-activation } \\
\text { concrete }\end{array}$ & $\begin{array}{c}1 / 100 \\
\text { low-activation } \\
\text { concrete }\end{array}$ & $\begin{array}{c}1 / 10 \\
\text { low-activation } \\
\text { concrete }\end{array}$ & JPDR concrete \\
\hline & $\begin{array}{c}\text { Type WA-CAS } \\
-1.0 \mathrm{~B} \\
\end{array}$ & $\begin{array}{c}\text { Type HA-W } \\
-1.0 \mathrm{~B} \\
\end{array}$ & $\begin{array}{c}\text { Type HA-L } \\
-0.1 \mathrm{~B} \\
\end{array}$ & $\begin{array}{c}\text { Type HA-L } \\
-0.0 \mathrm{~B} \\
\end{array}$ & \\
\hline $\mathrm{H}$ & $1.67 \mathrm{E}-02$ & $1.24 \mathrm{E}-02$ & $1.17 \mathrm{E}-02$ & $1.17 \mathrm{E}-02$ & $1.400 \mathrm{E}-02^{\mathrm{a})}$ \\
\hline B & $1.02 \mathrm{E}-03$ & $1.02 \mathrm{E}-03$ & $1.02 \mathrm{E}-04$ & $0.00 \mathrm{E}+00$ & $0.0000 \mathrm{E}+00$ \\
\hline $\mathrm{C}$ & $6.16 \mathrm{E}-06$ & $1.05 \mathrm{E}-02$ & 1.09E-02 & $1.09 \mathrm{E}-02$ & $0.0000 \mathrm{E}+00$ \\
\hline $\mathrm{O}$ & $5.18 \mathrm{E}-02$ & $4.32 \mathrm{E}-02$ & $4.34 \mathrm{E}-02$ & $4.34 \mathrm{E}-02$ & $4.5134 \mathrm{E}-02$ \\
\hline $\mathrm{Na}$ & $7.29 \mathrm{E}-05$ & $2.17 \mathrm{E}-05$ & $2.20 \mathrm{E}-05$ & $2.20 \mathrm{E}-05$ & $8.4026 \mathrm{E}-04$ \\
\hline $\mathrm{Mg}$ & $2.17 \mathrm{E}-05$ & $1.57 \mathrm{E}-04$ & $1.79 \mathrm{E}-04$ & $1.79 \mathrm{E}-04$ & $0.0000 \mathrm{E}+00$ \\
\hline $\mathrm{Al}$ & $2.56 \mathrm{E}-02$ & $2.25 \mathrm{E}-04$ & $1.56 \mathrm{E}-04$ & $1.56 \mathrm{E}-04$ & $2.6571 \mathrm{E}-03$ \\
\hline $\mathrm{Si}$ & $9.27 \mathrm{E}-04$ & $9.22 \mathrm{E}-04$ & $9.93 \mathrm{E}-04$ & $9.93 \mathrm{E}-04$ & $1.6072 \mathrm{E}-02$ \\
\hline $\mathrm{Ca}$ & $2.87 \mathrm{E}-03$ & $1.32 \mathrm{E}-02$ & $1.32 \mathrm{E}-02$ & $1.32 \mathrm{E}-02$ & $2.5612 \mathrm{E}-03$ \\
\hline $\mathrm{Fe}$ & $1.17 \mathrm{E}-05$ & $1.04 \mathrm{E}-05$ & $1.02 \mathrm{E}-04$ & $1.02 \mathrm{E}-04$ & $4.8571 \mathrm{E}-04$ \\
\hline $\mathrm{Li}(\mathrm{g} / \mathrm{g})$ & $7.40 \mathrm{E}-07$ & 1.13E-06 & $3.51 \mathrm{E}-06$ & $3.51 \mathrm{E}-06$ & $1.40 \mathrm{E}-05$ \\
\hline $\mathrm{N}(\mathrm{g} / \mathrm{g})$ & $2.00 \mathrm{E}-05$ & $9.00 \mathrm{E}-06$ & $5.77 \mathrm{E}-05$ & $5.77 \mathrm{E}-05$ & $4.00 \mathrm{E}-05$ \\
\hline $\mathrm{Cl}(\mathrm{g} / \mathrm{g})$ & $1.03 \mathrm{E}-05$ & $6.37 \mathrm{E}-05$ & $3.03 \mathrm{E}-05$ & $3.03 \mathrm{E}-05$ & $5.00 \mathrm{E}-05$ \\
\hline Co $(\mathrm{g} / \mathrm{g})$ & $5.98 \mathrm{E}-08$ & $3.92 \mathrm{E}-07$ & $1.47 \mathrm{E}-06$ & $1.47 \mathrm{E}-06$ & $6.20 \mathrm{E}-06$ \\
\hline $\mathrm{Ni}(\mathrm{g} / \mathrm{g})$ & $1.85 \mathrm{E}-05$ & $8.90 \mathrm{E}-06$ & $3.00 \mathrm{E}-06$ & $2.93 \mathrm{E}-06$ & $1.30 \mathrm{E}-05$ \\
\hline $\mathrm{Zn}(\mathrm{g} / \mathrm{g})$ & $7.00 \mathrm{E}-06$ & $5.61 \mathrm{E}-06$ & 7.14E-05 & $7.14 \mathrm{E}-05$ & $6.92 \mathrm{E}-05$ \\
\hline $\mathrm{Nb}(\mathrm{g} / \mathrm{g})$ & $6.80 \mathrm{E}-07$ & $3.00 \mathrm{E}-07$ & $4.70 \mathrm{E}-07$ & $4.70 \mathrm{E}-07$ & $1.20 \mathrm{E}-05$ \\
\hline $\mathrm{Sn}(\mathrm{g} / \mathrm{g})$ & $8.10 \mathrm{E}-06$ & $0.00 \mathrm{E}+00$ & $8.30 \mathrm{E}-07$ & $8.30 \mathrm{E}-07$ & $2.00 \mathrm{E}-06$ \\
\hline $\mathrm{Ba}(\mathrm{g} / \mathrm{g})$ & $2.40 \mathrm{E}-06$ & $1.20 \mathrm{E}-05$ & $3.33 \mathrm{E}-05$ & $3.33 \mathrm{E}-05$ & $4.00 \mathrm{E}-04$ \\
\hline Cs $(\mathrm{g} / \mathrm{g})$ & $1.08 \mathrm{E}-08$ & $1.60 \mathrm{E}-07$ & $2.90 \mathrm{E}-07$ & $2.90 \mathrm{E}-07$ & $2.00 \mathrm{E}-06$ \\
\hline Sm (g/g) & $3.10 \mathrm{E}-06$ & $1.60 \mathrm{E}-07$ & $2.30 \mathrm{E}-07$ & $2.30 \mathrm{E}-07$ & $5.00 \mathrm{E}-06$ \\
\hline $\mathrm{Eu}(\mathrm{g} / \mathrm{g})$ & $1.06 \mathrm{E}-08$ & 4.94E-08 & $1.15 \mathrm{E}-07$ & $1.15 \mathrm{E}-07$ & $5.90 \mathrm{E}-07$ \\
\hline $\mathrm{U}(\mathrm{g} / \mathrm{g})$ & $7.30 \mathrm{E}-07$ & $6.20 \mathrm{E}-07$ & $1.11 \mathrm{E}-06$ & $1.11 \mathrm{E}-06$ & - \\
\hline $\mathrm{g} / \mathrm{cm}^{3}$ & 2.81 & 2.34 & 2.34 & 2.34 & 2.30 \\
\hline
\end{tabular}

a) Adjusted value cited from Hayashi K., et al. (Ref.7). 
The neutron transport and activation calculations for the JPDR experiment ${ }^{8)}$ were performed to evaluate the ability of low-activation regarding $1 / 10$ and $1 / 100$ types of lowactivation concrete just prior to this calculation. Figure 1 presents the maps of calculated total and thermal neutron fluxes for two-dimensional geometry of JPDR. ${ }^{9)}$ The neutron transport calculation was performed by using two-dimensional $\mathrm{S}_{\mathrm{N}}$ code DORT ${ }^{10)}$ with the MATXSLIBJ33T10 library ${ }^{11}$ which was prepared for activation calculation to obtain correct thermal energy spectrum. The MATXSLIB-J33T10 library was processed from evaluated cross section library JENDL 3.3 by using NJOY $99.83^{12)}$. This figure indicates that the thermal neutron flux is overwhelmingly dominant in the concrete shield.

Figure 2 illustrates the estimated maps of low level wastes for JPDR shield wall, comparing ordinary concrete with $1 / 10$ and $1 / 100$ types of low-activation concrete. Activation calculation was performed using the obtained neutron flux and MATXSLIB-J33T10 activation cross section library and ORIGEN-79 $\operatorname{code}^{13)}$. The Japanese regulations of low level radioactive waste, such as LLW class 2, LLW class 3 and clearance class, were applied for classification. This figure shows that the area of LLW class 3 decreases distinctly by adopting $1 / 10$ or $1 / 100$ type of low-activation concrete, and especially that almost all the area of LLW class 2 disappears by adopting 1/100 type of low-activation concrete.

We next tried to simulate the most appropriate multilayer structure by using one dimensional (1-D) $\mathrm{S}_{\mathrm{N}}$ code ANISN ${ }^{14)}$ and the geometry as shown in Fig. 3. The case 1 is for the JPDR concrete and the case 2 is for the reference multilayer shielding structure as arranged 1/10,000,1/1,000,1/100 and $1 / 10$ types of low-activation concrete and JPDR concrete. Source spectrum and flux density were cited from Sukegawa T, et al. [Ref.8]. For the JPDR concrete, the 1-D calculation using DLC-23F cross section library ${ }^{15)}$ was performed, as illustrated in Fig. 4, to adjust to the 1-D source condition. Under the same source condition, we calculated $\sum \mathrm{Di} / \mathrm{Ci}$ values of the JPDR concrete and the reference multilayer low-activation concrete, as plotted in Fig. 5. The area of "LLW class 3" decreases drastically and also the area of "LLW class 2" disappears completely by adopting such multilayer low-activation concrete. A notable fact is that the total neutron flux of the concrete surface for Advanced Boiling Water Reactor (ABWR) or Advanced Pressurized Water Reactor (APWR) is not exceeded that for JPDR, therefore almost all the shielding concrete of ABWR or APWR will be classified below clearance level on decommissioning by adopting such low-activation multilayer shielding structures.

\section{Conclusion}

Low-activation multilayer shielding structure of light water reactor has been designed using various types $(1 / 10$, $1 / 100,1 / 1,000$ and $1 / 10,000)$ of low-activation concrete composed of low-activation raw materials. As an example, iterative calculations of induced activities and $\Sigma \mathrm{Di} / \mathrm{Ci}$ values of multilayer model for JPDR have been performed by using a discrete ordinate code. It is concluded that most of the shielding concrete of JPDR would be classified below clearance level on decommissioning by adopting such low-activation multilayer shielding structures.

\section{Acknowledgment}

We are grateful to Prof. Shinya Kitamura and Associate Prof. Tomohiko Iwasaki of Tohoku University, Mr. Nagao Kakinuma and Mr. Motomu Suzuki of graduate school of Tohoku University, Mr. Minoru Saito of Tohoku Electric Co., Mr. Masaki Takimoto, Dr. Hiroichi Tomotake and Mr. Shinya Satake of Taiheiyo Cement Co. for discussions and comments. This work was financed by a Grant-in-Aid from the Innovative and Viable Nuclear Energy Technology (IVNET) development project of the Ministry of Economy, Trade and Industry, Japan.

\section{References}

1) IAEA Safety Standards Series, "Application of the Concept of Exclusion, Exemption and Clearance", No. RS-G-1.7 (2004).

2) M. Kinno, K. Kimura, et al., "Raw Materials for Low-Activation Concrete Neutron Shields," J. Nucl. Sci. Technol., 39, No. 12, 1275 (2002).

3) M. Kinno, K. Kimura, et al., "Development of Low-Activation Reinforced Concrete Design Methodology-(2) Manufacture of Low-Activation Concrete" Proc. 11th International Conference on Radiation Shielding, Atlanta, USA, Apr. 13-18, (2008).

4) M. Kinno, K. Kimura et al., Development of Low-Activation Design Method for Reduction of Radioactive Waste (3) Various Types of Various Types of Low-Activation Concrete, Proc. 16th Pacific Basin Nuclear Conference (PBNC), P16P1437, Oct. 13-18, Aomori, Japan, 2008.

5) K. Ichitsubo, et al., "Low-Activation Reinforced Concrete Design Methodology (6) Development of Low-Activation Cement", Transactions, 19th International Conference on Structural Mechanics in Reactor Technology, Toronto, Canada, Paper\# HW1/2 (2007).

6) R. Yoshino, et al., "Development of Low-Activation Design Method for Reduction of Radioactive Waste below Clearance Level (7) Application of High Alumina Cement for LowActivation mortar", Transactions, 19th International Conference on Structural Mechanics in Reactor Technology, Toronto, Canada, Paper\# HW1/3 (2007).

7) K. Hayashi, et al., "Development of Low- activation reinforced concrete design methodology-I: Concrete Activation Analyses of BWR/PWR, Nuclear Technology, Nov. 2009, to be published.

8) T. Sukegawa, et al., Accuracy Verification for Calculation of Inventory in JPDR due to Neutron Activation, IAEA-NEA INDC (JPN)-164 (1993).

9) K. Yamaguchi, et al., "Development of Low-Activation Design Method for Reduction of Radioactive Waste below Clearance Level (40) - Application of Classification - Mapping System to JPDR", Preprints 2008 Spring Mtg., At. Energy Soc. Jpn., C4, (2008), [in Japanese].

10) W. A. Rhoades, and R. L. Childs, "The DORT Two-Dimensional Discrete Ordinates Transport Code" Nuclear Science \& Engineering, 99, 1, 88-89 (May 1988).

11) M. Uematsu, et al., Development of Low-Activation Design Method for Reduction of Radioactive Waste (2) Precise Neutron Flux and Activation Estimation of Nuclear Power Plants using 
MATXSLIB-J33T10, Proc. 16th Pacific Basin Nuclear Conference (PBNC) , P16P1438, Oct. 13-18, Aomori, Japan, 2008.

12) R. E. MacFarlane, and D. W. Muir, "The NJOY Nuclear Data Processing System Version 91", LA-12740-M (1994).

13) "ORIGEN-79: Isotope Generation and Depletion Code - Matrix Exponential Method", ORNL, CCC-217(1976).
14) W.W. Engle Jr., “A User Manual for ANISN: A One-Dimensional Discreet Ordinates Transport Code with Anisotropic Scattering", ORNL-23 Updated (1981).ORNL, K-1963 (1967).

15) R. W. Roussin, et al., "CASK-81 - 22 Neutron, 18 Gamma-RayGroup, P3, Cross Sections for Shipping Cask Analysis", ORNL-23 Updated (1981).

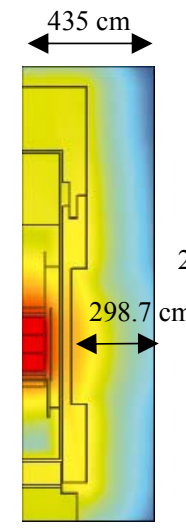

Total neutron flux

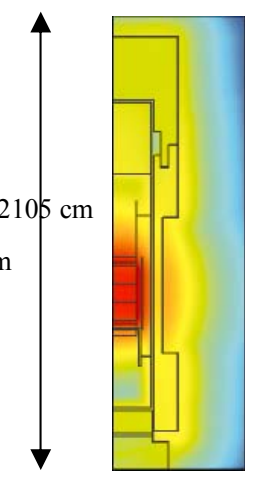

Thermal neutron flux $(\mathrm{E}<0.414 \mathrm{eV})$

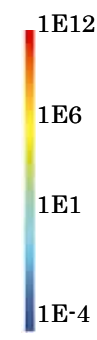

$\left(\mathrm{n} \mathrm{sec}{ }^{-1} \mathrm{~cm}^{-2} \mathrm{MW}^{-1}\right.$ )

Fig. 1 Calculated total and thermal neutron fluxes of JPDR [Ref.9]

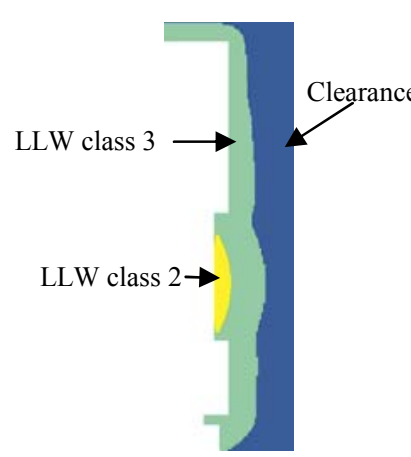

JPDR concrete

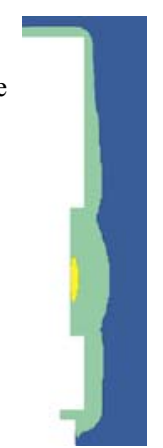

1/10 low-activation concrete

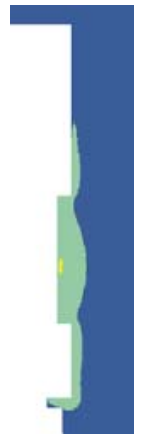

1/100 low-activation concrete

Fig. 2 Comparison of estimated maps of low level wastes between ordinary concrete and reference low-activation concrete for JPDR shield wall [Ref.9]

- Case 1: JPDR concrete

JPDR concrete $298.7 \mathrm{~cm}$

\section{- Case 2: Multilayer low-activation concrete}

\begin{tabular}{|c|c|c|c|c|}
\hline $\begin{array}{c}1 / 10,000 \\
\text { low-activation } \\
\begin{array}{c}\text { Concrete } \\
40 \mathrm{~cm}\end{array}\end{array}$ & $\begin{array}{c}1 / 1,000 \\
\text { low-activation } \\
\text { concrete } \\
40 \mathrm{~cm}\end{array}$ & $\begin{array}{c}1 / 100 \\
\text { low-activation } \\
\text { concrete } \\
30 \mathrm{~cm}\end{array}$ & $\begin{array}{c}1 / 10 \\
\text { low-activation } \\
\text { concrete } \\
30 \mathrm{~cm}\end{array}$ & $\begin{array}{c}\text { JPDR concrete } \\
158.7 \mathrm{~cm}\end{array}$ \\
\hline $0 \mathrm{~cm}$ & $40 \mathrm{~cm}$ & \multicolumn{2}{c|}{$110 \mathrm{~cm}$} & $140 \mathrm{~cm}$
\end{tabular}

Fig. 3 Reference one dimensional geometry of JPDR shield wall

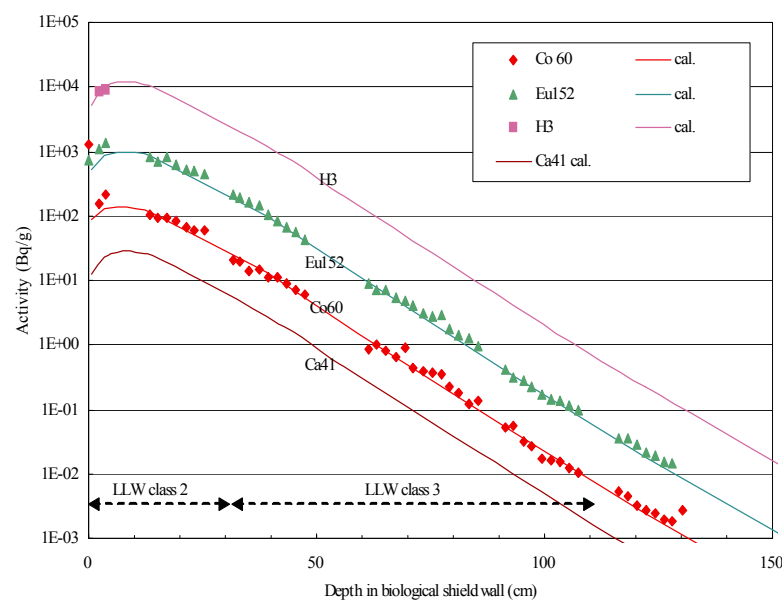

Fig. 4 Comparison of measured [Ref.8] and calculated radioactivities

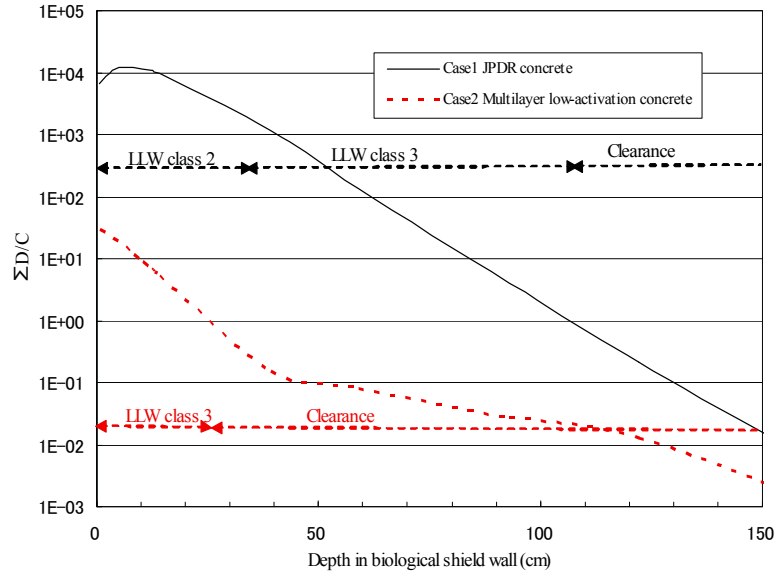

Fig. 5 Comparison of JPDR concrete and multilayer low-activation concrete 